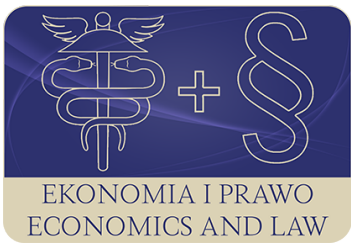

EKONOMIA I PRAWO. ECONOMICS AND LAW

Volume 19, Issue 2, June 2020

p-ISSN 1898-2255, e-ISSN 2392-1625

www.economicsandlaw.pl

EKONOMIA I PRAWO
ECONOMICS AND LAW

ORIGINAL ARTICLE

received 30.03.2019; revised 20.12.2019; accepted 30.06.2020

Citation: Zieliński, M. (2020). The impact of the unemployment level on non-standard employment forms in the Visegrad Group countries. Ekonomia i Prawo. Economics and Law, 19(2): 393-404.

doi:10.12775/EiP.2020.027.

\title{
The impact of the unemployment level on non-standard employment forms in the Visegrad Group countries
}

\author{
MARIUSZ ZIELIŃSKI \\ Opole University of Technology, Faculty of Economics and Management, Department \\ of Organization and Enterprise Management, ul. Luboszycka 7, 45-036 Opole, Poland \\ $\square$ m.zielinski@po.edu.pl \\ D orcid.org/0000-0002-2121-1339
}

\begin{abstract}
Motivation: The scale of presence of non-standard forms of employment in the different economies depends on the laws in force, the offer on the demand side (employers), and the interest in that offer on the supply side (employees). Non-standard employment is more beneficial to employers than to employees because it often involves worse work-

ing conditions and lower wages. The evaluation of the relationship between the level of unemployment and the share of non-standard employment forms in Visegrad Group countries includes a comparison of the changes in the unemployment level and the share of non-standard employment forms in employment in the 15-64 age group. In order to verify the hypothesis, the coefficients of correlation and determination between the unemployment rate and the employment in non-standard forms were calculated. Aim: The purpose of the article is to study the relationship between the unemployment rate and the share of non-standard forms in employment in a selected group of countries in the long term. The hypothesis is that changes in the unemployment level are related to changes in the share of non-standard forms in employment.

Results: The hypothesis of the article was not confirmed in most of the analyzed cross-sections. Although a statistically significant relationship was observed between the unemployment rate and part-time employment, in a half of the studied countries the relationship was positive and in the other half - negative. The only exception was Poland, due to the very high correlation between the unemployment rate and all the analyzed non-standard employment forms, which was confirmed by high determination coefficient.
\end{abstract}


Keywords: unemployment rate; non-standard employment; Visegrad Group countries JEL: E24; J20; J21; J70

\section{Introduction}

The scale of application of flexible forms of employment in individual economies depends on the current legal standards, the offer on the demand side (companies) and the interest on the supply side (employees). Non-standard employment with its main forms including employment for a limited period of time, employment on a part-time basis and self-employment is more beneficial for the employers than for the employees, due to the fact that it is often related to worse terms of work and lower wages. Readiness to accept work in non-standard forms on the part of employees depends on the current situation at individual labour markets and spikes in periods of high unemployment. Therefore, it may be expected that there is a relation between the level of unemployment and the share of non-standard forms in employment in general.

The author of the paper analyses the relation between the unemployment rate and the share of non-standard forms of employment in a selected group of countries, in a long-term perspective. The purpose of the paper is to verify the flexibility of the structure of employment to changes in economic situation and to check whether such reaction is similar in all analysed countries. The hypothesis is a statement that changes in the level of unemployment rate are related to the share of non-standard forms in employment. The research period spans from 2004 when countries from the Visegrad Group joined the EU to 2017, which is the last year for which comparable data are available.

The following parts of the paper present a review of literature, the applied methodology, the analysis of changes in the unemployment rate and the share of non-standard employment in total employment and the analysis of correlation and determination occurring between these values. The paper ends with a discussion and conclusions.

\section{Non-standard form of employment in theoretical approach}

Non-standard employment takes place when at least one of the terms of standard employment has not been met, which include: employment for an unlimited period of time, full time dimension of work, work at fixed times and in a designated place. Non-standard forms of employment are favourable for employers, due to the fact that they are related to limited labour costs (costs of employee benefits, social benefits, un-worked hours and holiday leave), and they also make it easier to terminate the contract in a worse economic situation, along with a potential increase of such employment in the period of accelerated economic growth (Gaston \& Kishi 2007, pp. 436-437; Hauseman, 2001, pp. 149-154; Kalleberg et al., 2003, pp. 546-547). Employers use flexible forms of employment in a scale dependent on the possibilities created by legal stand- 
ards and the current economic situation. The increase in the share of non-standard employment in total employment is favoured by unstable demand for work related to the changes in the economic situation (Bloisi, 2007, pp. 88-89; Noe et al., 2006, pp. 188-190; Zieliński, 2018, pp. 330-331). The negative side of non-standard employment for employers is lower loyalty, lower identification with the company and usually lower efficiency of employees working in non-standard forms (Bryson et al., 2005, pp. 68-69, 80-81).

Employees have varied approach to work in a flexible manner, depending on the fact if this is their only form of employment (basic source of income) or whether it is an additional employment and whether the flexible employment was started at their choice or whether they were forced to start working in this mode due to the absence of work offers in a standard form. If this is their basic place of work, the employees prefer standard form of employment, due to the fact that non-standard forms of employment are related to: threat of remaining in the flexible labour market segment, higher probability of loss of work, worse work terms (varied work hours, varied length of work shifts), lower wages and social benefits, lower possibility of promotion, worse development possibilities, as well as lower creditworthiness increasing insecurity of existence (Fouarge et al., 2012, pp. 181-182; Need et al., 2005, pp. 164-166). The employees who are satisfied with flexible forms of work use them to acquire additional income and persons whose non-professional obligations prevent them from commencement of work on a full-time basis (e.g. persons who take care of children or elderly persons) (Amuedo-Dorantes \& Serrano-Padial , 2010, p. 633).

Commencement of flexible employment even against one's preferences (for example in the period of high unemployment) offers employees certain benefits in the form of: possibility of gaining employment, professional experience and defending against the loss of professional qualifications, increasing chances for finding standard employment, possibility of entering the labour market (in the case of graduates) or possibility of leaving the labour market gradually (in the case of old-age persons) (Babos, 2014, pp. 39-40, 47; Bertrand-Cloodt et al., 2012, p. 158).

From the perspective of the subject matter of this paper, it is important to note which type of the employers' and employees' behaviour decides about the scale of non-standard employment, depending on the economic situation and the rate of unemployment related to it. Relations between these values may vary, depending on its form. Non-standard forms of employment most often include temporary employment (contracts), part-time employment and self-employment.

Temporary employment allows greater flexibility of demand for work; the employer does not have to prolong a contract with an employee, does not bear any financial costs on account of this and frequently also offers lower wages to temporary employees (Debels, 2005, pp. 3-4). Temporary employment contracts are concluded primarily with employees in a trial period, who work 
as replacement, and with seasonal employees, who satisfy the personnel needs of a company in the periods of increased demand for its products and services (Hauseman, 2001, pp. 150-151). If employers have the negotiating advantage at the labour market (e.g. in the conditions of high unemployment), they can increase the share of temporary employment in order to facilitate a potential reduction in employment in the period of worse economic situation. In relation to this, the share in employment of persons hired for a limited time usually grows in a good economic situation (drop in unemployment) and is decreased in the period of worse economic situation, due to the fact that persons employed for a limited period of time lose work more frequently.

The employer's decision on part-time work may result from a specific nature of a work position (the task does not have to be performed continuously, there is no full-time workload with respect to it), 'work sharing' in periods of weak market or supplementing personnel in the periods of economic boom with the use of persons who cannot or do not want to work on a full-time basis (Industrial Relations Services, 2001, pp. 4-10). Work sharing is a strategic-type decision when the employer, in agreement with the employees, decides to reduce the workload (and to reduce pay adequately) in the period of a drop in demand for the company's products and services, which is an alternative for reduction in employment (Bloisi, 2007, p. 68). Work sharing from the employer's perspective allows for keeping qualified personnel in the period of economic crisis; from the employees' perspective it allows for retaining - even though part-time - employment, yet in the conditions of absence of alternative work offers. Work sharing may be supplemented by a periodical reduction of work hours. Employees may also search for part-time work if they cannot or do not want to work on a full-time basis (e.g. persons who combine family obligations with professional activities, persons who undertake additional employment) (Russo \& Hasink, 2008, pp. 146-150). Changes in the share of part-time employment in compliance with the direction of changes in the economic situation occur when persons who are a supplement for the personnel are employed in these forms (auxiliary or seasonal personnel). At the peak of a market boom (with low level of unemployment), the number of such personnel is increased and in the period of market slump, these employees are the first to lose employment. The participation of part-time employees in work sharing has an opposite direction to the changes in economic situation (employment of a greater number of employees at one position who share the wages and benefits).

Self-employment is a form of conducting own small-scale business activity. If it is undertaken upon the initiative of the employee, the change in share of self-employed is consistent with changes in the economic situation it is easier to start a business and remain at the market in a period of economic growth. However, some self-employed commence business activity under pressure of their hitherto employer. In periods of slumping market, employers may as part of restructuring limit permanent employment by partially outsourcing tasks, including to their hitherto employees who started own business (which 
increases the scope of self-employment). Share of self-employed persons in employment reacts to changes in the business outlook depending on the proportion of persons who commence self-employment on their own initiative or are forced to do so by the employer (Blundell et al., 2014, pp. 13-15). If the latter of the above-listed groups is dominant, the share of self-employed persons in the total employment grows along with the growth of unemployment rate.

The point of reference for studies performed in this paper is the situation at the Spanish labour market. It was observed that the effects of high share of non-standard forms of employment in total employment depend, to a significant degree, on the economic situation (Eamets \&Jaakson, 2014, pp. 747-750). In the conditions of rapid economic growth, non-standard employment is conducive to quick reduction in the unemployment rate, e.g. extension of the scope of application of temporary employment has allowed to significantly reduce the unemployment rate in Spain in the 1990s (Amuedo-Dorantes \& Serrano-Padial, 2010, pp. 633-635; Gonzalez \& Miles-Touya, 2012, pp. 833-835). Unfortunately, a high share of temporary contracts translated to a rapid increase in unemployment in this country after 2008. In the case of Spain, studies conducted on the basis of quarterly data for the period 1987-2010 showed that in the periods of market slump, dismissals affected primarily temporary workers. It was estimated that between 1987 and 2010 , as much as $84.4 \%$ of the gross flows between unemployment and employment were changes in the level of employment at temporary contracts. A strong positive relation was recorded between changes in the GDP and the flow from unemployment to temporary employment and a strong negative relation between flows between temporary work and unemployment (Silva \& Vazquez-Grenno, 2013, pp. 164-168).

\section{Methods}

Evaluation of the relation between the unemployment rate and the share of non-standard forms in employment in the Visegrad Group countries (Czechia, Hungary, Poland, Slovakia) was made on the basis of data published by Eurostat (2019). Four countries were selected with a similar level of economic development and a similar economic history which joined the European Union at the same moment. Thanks to this, it may be assumed that on the international and macro-economic scale, the situation of the analysed economies is similar.

All of the data used in the paper refer to the group between 15 and 64 years of age. The comparison of changes in the level of unemployment rate in EU-28 and in four analysed countries from the moment of their joining the European Union, i.e. in 2004, until 2017, for which comparable data are available, is an introduction to the study. The next analysed breakdown in a table form pertains to changes in the level of share of non-standard forms of employment in total employment in four analysed countries. Data pertaining to share in employment of employees with contracts of limited duration and part-time employees were procured directly from tables published by Eurostat (2019). In the case 
of self-employed, it was necessary to calculate the quotient of the number of self-employed and total employment.

In a further part of the paper, to verify the proposed hypothesis, correlation and determination coefficients were calculated between the rate of unemployment and employment in three basic flexible forms (employees with contracts of limited duration, part-time employees and self-employed). A linear correlation analysis was selected for the purposes of the article, because if non-standard forms of employment are used to balance economic changes, a linear relationship between the level of employment / unemployment and the share of these forms in employment should be expected. An Exel spreadsheet was used for the calculations. The level of correlation of 0.01 (confidence level 0.99) was adopted as statistically significant. The strong side of the adopted methodology is the possibility of making international comparisons based on the comparable data procured from a single source. The time span of 14 years seems to be sufficient for drawing conclusions, whereas the analysed relations between values change along with changes in the situation on the labour market in individual countries. This observation is related to the weak side of the methodology consisting in the fact that shortening or lengthening the analysed period may change the calculated strength of correlation and determination among the analysed values.

\section{Correlation between unemployment rate and non-standard forms of employment in Visegrad Group countries}

Thirteen years of functioning as members of the European Union brought significant reduction in imbalance at the labour market for the Visegrad Group countries (table 1). At the beginning of the analysed period (2004), the unemployment rate in Czechia and in Hungary was lower than the average for EU28, whereas in the economies of Poland and Slovakia, the rate of unemployment was approx. two times higher than the EU average. Unemployment in all countries of the Visegrad Group countries was reduced faster than the EU average and in consequence, at the end of 2017, only Slovakia recorded a higher average level of unemployment than the EU. Relatively fastest drop in unemployment in the analysed period took place in Poland. It is to be noted that in Czechia in 2017, the unemployment rate dropped to the level of frictional unemployment, whereas in Hungary and Poland, it dropped below 5\%, which may be considered balancing of the labour market on the macro-economic scale (unemployment similar to a natural level, with frictional and structural nature).

Table 2 features the share of employment in three basic flexible forms (i.e. persons with contracts for limited duration, part-time workers and self-employed) in total employment. Non-standard forms of employment occurred definitely most often in Poland. In the first of the analysed years, such employment in total constituted $47.2 \%$ of overall employment and by the end of the analysed period, it dropped to $44.9 \%$ of all employed persons, whereas the share 
of all non-standard forms covered by the analysis was still highest among the Visegrad Group countries. It is to be noted that between 2004 and 2017, the share of non-standard forms in employment dropped in Hungary from $24.2 \%$ to $21.9 \%$ and grew from $27.4 \%$ to $30.2 \%$ in Czechia, whereas in Slovakia from $19 \%$ to $28.7 \%$. The most popular among the analysed non-standard forms of employment was definitely self-employment, whereas in the case of Poland, it has been occupying the second place after employment for a limited period of time (contracts) since 2006.

Table 3 contains a calculation pertaining to correlation and determination between the rate of unemployment and the level of share of individual non-standard forms of employment.

The relation between the unemployment rate and part-time employment was the only value of statistic significance in all analysed countries. The strongest relation on the level of significance of 0.001 was observed in Poland; in other analysed countries and in EU-28 as a whole, the relation was statistically significant on the level of 0.01. It is to be noted that in contrast to Poland, Hungary and the average of EU-28, the dependence between the unemployment rate and the share of part-time employment is negative in Czechia and Slovakia. Taking the unemployment rate which is twice as high in Slovakia as compared to Czechia into account, this indicates institutional similarities of these labour markets (in the area of cooperation between employers and employees). In contrast to other examined economies, in Czechia and Slovakia the effect of reduced employment of auxiliary employees working on a part-time basis was stronger than protection from dismissals by sharing work places during growing unemployment.

A negative relation between the level of unemployment and the share in employment of persons working at contracts and for limited duration became statistically significant for the EU-28 average (on the level of significance of 0.01) and in Poland (on the level of significance of 0.001). In other analysed countries, this relation turned out statistically insignificant, thus there is no mass scale reduction of employment of contract employees during weak market periods.

If a strong determination coefficient exceeding $50 \%$ is adopted, apart from Poland no other country (and the EU average) offers confirmation for the relation between the unemployment rate and the share of non-standard forms in employment. On the other hand for Poland, the determination between the unemployment rate and non-standard forms of employment for years 2004-2017 amounted to: 61.6\% in case of contracted employees, $81.9 \%$ in case of part-time employees and $91.6 \%$ in case of self-employed.

The results of the analysis of correlation and determination show that in Poland, a growth in unemployment rate results in much higher (than the average value for employees in total) drop in the share of contract workers and growth in the share of part-time workers and self-employment, whereas reverse processes take place during a drop in unemployment rate. Such dependencies show that in the analysed period, there was a definite dominance of the demand 
side on the Polish market and the employers shifted the business trend risks to the employees. In recession periods, the employers contributed to an increase in the rate of unemployment, by not extending limited duration contracts. In order to reduce the costs of labour, they forced the employees to set up their own business and provide work on the basis of self-employment. An increase in the share of part-time employees in periods of growing unemployment may indicate sharing of work places (in order to limit the scale of layoffs and to retain qualified employees) and/or dismissals, during recession, of persons employed on a full-time basis in the first place, in order to reduce labour costs.

\section{Discussion and results}

The hypothesis presented in the introduction was not confirmed in the majority of the analysed cross-sections. Even though a relation was observed between the unemployment rate and part-time employment, yet in the case of a half of the countries, this relation was positive and in the other half negative. In the case of Poland, the relation was not supported by adequately high determination coefficients. Taking this into account, broadly understood institutional determinants require further in-depth studies, in particular the relations between employers and employees, which determined the direction of correlation between the unemployment rate and part-time employment. The relation between the level of unemployment and the share in employment of contracted employees and employees hired for a limited period of time became statistically significant only for the EU-28 average and for Poland.

The only, yet very significant, exception from the perspective of the proposed hypothesis in the paper is Poland, where there was a very high correlation between the unemployment rate and all analysed forms of non-standard employment. This indicates a much higher flexibility of the Polish labour market as compared to other countries, whereas the direction of correlation between the analysed values shows a definite advantage on the employer's side on the labour market. This observation was confirmed by high determination coefficients between the unemployment rate and non-standard forms of employment in Poland. Determination of the degree to which a very high positive correlation between the unemployment rate and part-time employment results from work sharing requires further in-depth studies in the case of Poland.

\section{Conclusion}

It is to be noted that very high flexibility of the Polish labour market was accompanied by a relatively greatest drop in the rate of unemployment in the analysed period. It should not be assumed that high flexibility of the labour market could have contributed to a reduced imbalance over a long period in a macro-economic scale. The case of Spain shows that high flexibility, manifested by significant share of non-standard employment, translates to an increase in fluctuations 
in the level of employment and unemployment and not a reduction in the imbalance at the labour market. In Poland, the basic factors for the drop in unemployment rate after joining the EU seem to include highest economic growth among the analysed countries and demographic processes, resulting in a drop in a number of people in production age. However, it may be assumed that persistence of the low level of unemployment in Poland will result in a successive drop in the share of non-standard forms of employment.

\section{References}

Amuedo-Dorantes, C., \& Serrano-Padial, R. (2010). Labor market flexibility and poverty dynamics. Labour Economics, 17(4). doi:10.1016/j. labeco.2010.01.004.

Babos, P. (2014). Step or trap? Transition from fixed-term contracts in Central Eastern Europe. Post-Communist Economies, 26(1). doi:10.1080/14631377.2 014.874230 .

Bertrand-Cloodt, D., Cörvers, F., Kriechel, B., \& van Thor J. (2012). Why do recent graduates enter into flexible jobs? De Economist, 160(2). doi:10.1007/ s10645-011-9185-2.

Bloisi, W. (2007). An introduction to human resource management. London: McGraw Hill.

Blundell, R., Crawford, C., \& Jin, W. (2014). What can wages and employment tell us about the UK's productivity puzzle? The Economic Journal, 124(576). doi:10.1111/ecoj.12138.

Bryson, A., Cappellari, L., \& Lucifora, C. (2005). Job satisfaction and employer behavior. In S. Bazen, C. Lucifora, \& W. Salverda (Eds.), Job quality and employer behavior. London: Palgrave Macmillan.

Debels, A. (2005). The structuring of labour market dynamic along the permanent-temporary distinction: a comparision of Denmark, France, Spain and United Kingdom. Paper presented at the Conference of the European Panel Users Network. 30 June-2 July 2005, Colchaster. Retrieved 10.01.2019 from http://www.iser.essex.ac.uk.

Eamets, R., \& Jaakson, K. (2014). Labour market flexibility and spatial mobility. International Journal of Manpower, 35(6). doi:10.1108/ijm-05-2014-0123.

Eurostat. (2019). Retrieved 10.01.2019 from https://ec.europa.eu.

Fouarge, D., de Grip, A., Smits, W., \& de Vries, R. (2012). Flexible contracts and human capital investments. De Economist, 160(2). doi:10.1007/ s10645-011-9179-0.

Gaston, N., \& Kishi, T. (2007). Part-time workers doing full-time work in Japan. Journal of the Japanese and International Economies, 21(4). doi:10.1016/j. jjie.2006.04.001.

Gonzalez, X., \& Miles-Touya, D. (2012). Labor market rigidities and economic efficiency: evidence from Spain. Labour Economics, 19(6). doi:10.1016/j. labeco.2012.08.006. 
Hauseman, S.N. (2001). Why employers use flexible staffing arrangements: evidence from an establishment survey. Industrial and Labor Relations Review, 55(1). doi:10.1177/001979390105500109.

Industrial Relations Services. (2001). Part-time workers: in from the periphery. IRS Employment Trends, 725.

Kalleberg, A.L., Reynolds, J., \& Marsden, P.V., (2003). Externalizing employment: flexible staffing arrangements in US organizations. Social Science Research, 32(4). doi:10.1016/s0049-089x(03)00013-9.

Kehoe, J., \& Dickter, D. (2006). Customer service quality selecting value performers. In L. Fogli (Ed.), Customer service delivery. San Francisco: Jossey-Bass.

Need, A., Steijn, B., \& Gesthuizen, M. (2005). Long-term effects of flexible work. In B. Peper, A. von Doorne-Huiskes, \& L. den Dulk (Eds.), Flexible working and organizational change: the integration of work and personal life. Cheltenham: Edward Elgar.

Noe, R., Hallenbeck, J., Gerhart, B., \& Wright, P. (2006), Human resource management, gaining a competitive advantage. Boston: McGraw-Hill.

Russo, G., \& Hassink, W. (2008). The part-time wage gap: a career perspective. De Economist, 156(2). doi:10.1007/s10645-008-9087-0.

Silva, J.I., \& Vazquez-Grenno, J. (2013). The ins and outs of unemployment in a two-tier labor market. Labour Economics, 24. doi:10.1016/j. labeco.2013.08.009.

Zieliński, M. (2018). Effect of economics situation on employment and its structure in the Central and Eastern European countries. Ekonomia i Prawo Economics and Law, 17(3). doi:10.12775/EiP.2018.024.

\section{Acknowledgements}

Author contributions: author has given an approval to the final version of the article.

Funding: this research was funded by the Opole University of Technology, Faculty of Economics and Management statutory sources.

Note: the results of this study were presented at 10th International Conference on Applied Economics Contemporary Issues in Economy (June 27-28, 2019, Torun, Poland). 


\section{Appendix}

Table 1.

Changes in unemployment rate in the Visegrad Group countries as compared to the European Union between 2004 and 2017 (in \%)

\begin{tabular}{lrrrrc}
\hline \multicolumn{1}{c}{ Year } & EU-28 & Czechia & Hungary & Poland & Slovakia \\
\hline 2004 & 9.3 & 8.3 & 6.1 & 19.1 & 18.4 \\
2005 & 9.0 & 7.9 & 7.2 & 17.6 & 16.4 \\
2006 & 8.2 & 7.1 & 7.5 & 13.9 & 13.5 \\
2007 & 7.2 & 5.3 & 7.4 & 9.6 & 11.2 \\
2008 & 7.0 & 4.4 & 7.8 & 7.1 & 9.6 \\
2009 & 9.0 & 6.7 & 10.0 & 8.1 & 12.1 \\
2010 & 9.6 & 7.3 & 11.2 & 9.7 & 14.5 \\
2011 & 9.7 & 6.7 & 11.0 & 9.7 & 13.7 \\
2012 & 10.5 & 7.0 & 11.0 & 10.1 & 14.0 \\
2013 & 10.9 & 7.0 & 10.2 & 10.3 & 14.2 \\
2014 & 10.2 & 6.1 & 7.7 & 9.0 & 13.2 \\
2015 & 9.4 & 5.1 & 6.8 & 7.5 & 11.5 \\
2016 & 8.6 & 4.0 & 5.1 & 6.2 & 9.7 \\
2017 & 7.6 & 2.9 & 4.2 & 4.9 & 8.1 \\
\hline
\end{tabular}

Source: Eurostat (2019).

Table 2.

Share of basic non-standard forms of employment in total employment in the Visegrad Group countries between 2004 and 2017 (in \%)

\begin{tabular}{cccccccrrrrrr}
\hline \multirow{2}{*}{ Year } & \multicolumn{3}{c}{ Czechia } & \multicolumn{4}{c}{ Hungary } & \multicolumn{3}{c}{ Poland } & \multicolumn{3}{c}{ Slovakia } \\
\cline { 2 - 13 } & LD & PT & SE & LD & PT & SE & LD & PT & SE & LD & PT & SE \\
\hline 2004 & 7.0 & 4.3 & 16.1 & 5.8 & 4.4 & 13.9 & 16.8 & 9.8 & 20.6 & 4.7 & 2.5 & 11.8 \\
2005 & 6.7 & 4.4 & 15.1 & 6.1 & 3.9 & 13.1 & 19.3 & 9.8 & 20.0 & 4.2 & 2.4 & 12.5 \\
2006 & 6.7 & 4.4 & 15.3 & 6.0 & 3.7 & 12.1 & 20.8 & 8.9 & 19.4 & 4.3 & 2.7 & 12.5 \\
2007 & 6.6 & 4.4 & 15.4 & 6.4 & 3.9 & 11.8 & 21.8 & 8.5 & 18.7 & 4.3 & 2.5 & 12.8 \\
2008 & 6.1 & 4.3 & 15.2 & 6.9 & 4.3 & 11.6 & 20.9 & 7.7 & 18.3 & 3.9 & 2.5 & 13.6 \\
2009 & 6.3 & 4.8 & 15.9 & 7.4 & 5.2 & 12.0 & 20.6 & 7.7 & 18.3 & 3.6 & 3.4 & 15.5 \\
2010 & 6.7 & 5.1 & 16.8 & 8.5 & 5.5 & 11.8 & 21.1 & 7.7 & 18.7 & 4.7 & 3.8 & 15.8 \\
2011 & 6.5 & 4.7 & 17.2 & 8.0 & 6.4 & 11.4 & 20.9 & 7.3 & 18.7 & 5.5 & 4.0 & 15.8 \\
2012 & 6.8 & 5.0 & 17.5 & 8.5 & 6.7 & 11.0 & 20.9 & 7.2 & 18.4 & 5.7 & 4.0 & 15.3 \\
2013 & 7.5 & 5.8 & 16.5 & 9.7 & 6.4 & 10.6 & 21.1 & 7.1 & 18.1 & 5.8 & 4.5 & 15.4 \\
2014 & 8.0 & 5.5 & 17.0 & 9.6 & 6.0 & 10.3 & 22.4 & 7.1 & 17.9 & 7.4 & 5.1 & 15.2 \\
2015 & 8.3 & 5.3 & 16.3 & 10.1 & 5.7 & 10.2 & 22.2 & 6.8 & 17.9 & 8.9 & 5.8 & 14.9 \\
2016 & 8.1 & 5.7 & 16.6 & 8.7 & 4.8 & 9.9 & 21.9 & 6.4 & 17.7 & 8.4 & 5.8 & 15.7 \\
2017 & 8.0 & 6.2 & 16.0 & 7.9 & 4.3 & 9.7 & 20.9 & 6.6 & 17.4 & 8.0 & 5.8 & 14.9 \\
\hline
\end{tabular}

Notes:

LD — employees with a contract of limited duration; PT — persons employed part time; se — self employed.

Source: Eurostat (2019). 
Table 3.

Coefficients of correlation with and determination of the level of unemployment and level of nonstandard employment

\begin{tabular}{lcc}
\hline \multicolumn{1}{c}{ Explanatory variables } & Correlation coefficients & Determination coefficients \\
\hline employed for a limited duration & EU-28 & 0.4078 \\
employed part-time & $-0.6386^{*}$ & 0.2180 \\
self-employed & $0.4669^{*}$ & 0.1820 \\
\hline & 0.4267 & 0.1957 \\
employed for a limited duration & Czechia & 0.2676 \\
employed part-time & -0.4424 & 0.0093 \\
self-employed & $-0.5173^{*}$ & \\
\hline & 0.0963 & 0.0460 \\
employed for a limited duration & Hungary & 0.4253 \\
employed part-time & 0.2145 & 0.0230 \\
self-employed & $0.6522^{*}$ & 0.6160 \\
\hline & 0.1518 & 0.8192 \\
employed for a limited duration & Poland & 0.9162 \\
employed part-time & $-0.7849^{* *}$ & \\
self-employed & $0.9051^{* *}$ & 0.1762 \\
\hline & $0.9572^{* *}$ & 0.2375 \\
employed for a limited duration & Slovakia & 0.1354 \\
\hline
\end{tabular}

Notes:

* statistically significant correlation at significance level of 0.01 /determination value considered significant for the model; ${ }^{* *}$ statistically significant correlation at significance level 0.001 .

Source: Own calculations. 